\title{
Long-Day Photoperiod that Enhances Puberty Does Not Limit Body Growth in Holstein Heifers ${ }^{\star} \dagger$
}

\author{
A. G. Rius, ${ }^{1}$ E. E. Connor ${ }^{2}$ A. V. Capuco, ${ }^{2}$ P. E. Kendall, ${ }^{1}$ \\ T. L. Auchtung-Montgomery ${ }^{1}$ and $\mathbf{G}$. E. Dahl ${ }^{1}$ \\ ${ }^{1}$ Department of Animal Sciences, University of Illinois, Urbana 61801 \\ ${ }^{2}$ USDA-ARS, BFGL, Beltsville, MD 20705
}

\begin{abstract}
Previous research has demonstrated that extended photoperiod accelerates pubescence in dairy heifers thereby limiting time for mammary development, which could be detrimental to future milk yield. We hypothesized that the potential negative effects of rapid growth and puberty through long-day photoperiod (LDPP) exposure could be overcome with a greater supply of metabolizable protein in dairy heifers fed rumenundegradable protein (RUP). In an initial slaughter study, we compared deuterium oxide $\left(\mathrm{D}_{2} \mathrm{O}\right)$ and direct chemical analysis to assess body composition at 5 and 7 mo of age in heifers $(n=20)$ exposed to LDPP or shortday photoperiod (SDPP). Before slaughter, $\mathrm{D}_{2} \mathrm{O}$ dilution was used to estimate body composition and results were compared with actual values determined by direct chemical analysis of body tissue. In 5-mo-old heifers, the correlations between estimates of body protein, water, and mineral contents as determined by $\mathrm{D}_{2} \mathrm{O}$ dilution and direct chemical analysis of body tissue were $0.86,0.85$, and 0.76 , respectively; however, fat content values were not correlated $(\mathrm{r}=-0.068)$. In 7 -mo-old heifers, we were unable to accurately estimate body composition using the $\mathrm{D}_{2} \mathrm{O}$ dilution method. A second study was conducted to determine if LDPP, which has previously been shown to hasten puberty, could be combined with RUP to promote lean growth without limiting body stature in prepubertal heifers. Thirty-two weaned heifers ( $86 \pm 2 \mathrm{~d}$ old; $106.2 \pm 17.3 \mathrm{~kg}$ of body weight) were assigned to LDPP or SDPP and RUP or control diet in a $2 \times 2$ factorial arrangement until the onset of puberty. Relative to SDPP, LDPP increased
\end{abstract}

Received May 26, 2005.

Accepted July 25, 2005.

Corresponding author: Geoffrey E. Dahl; e-mail: gdahl@uiuc.edu.

*Funding was provided by USDA-ARS Project No. 1265-31000086-01 and C-FAR Project \#01I-003-SEN.

$\dagger$ Mention of trade names or commercial products in this article is solely for the purpose of providing specific information and does not imply recommendation or endorsement by the U.S. Department of Agriculture. prolactin secretion and promoted lean growth. Exposure to LDPP also enhanced body weight, withers height, and heart girth. Furthermore, RUP supplementation increased withers height and heart girth. There was a significant interaction between LDPP and RUP for hip height. Moreover, LDPP hastened the onset of puberty. In summary, $\mathrm{D}_{2} \mathrm{O}$ was a feasible method to estimate lean composition in heifers at younger ages; however, it failed to accurately estimate body composition in heifers around puberty. Long-day photoperiod hastened puberty and accelerated lean growth without limiting skeletal growth in dairy heifers.

(Key words: photoperiod, protein, heifer, growth)

Abbreviation key: EBF = empty body fat, EBM = empty body mineral, $\mathbf{E B P}=$ empty body protein, $\mathbf{E B W}=$ empty body water, EBWT = empty body weight, $\mathbf{H G}=$ heart girth, $\mathbf{H H}=$ hip height, LDPP = long-day photoperiod, $\mathbf{P R L}=$ prolactin, $\mathbf{S D P P}=$ short-day photoperiod, $\mathbf{W H}=$ withers height.

\section{INTRODUCTION}

Dairy producers strive to adopt management techniques that reduce age at first parturition without impairing milk production potential. The use of long-day photoperiod (LDPP) to hasten the onset of puberty (Peters et al., 1980; Schillo et al., 1983) could potentially reduce the age of heifers at first parturition. However, accelerating puberty may have negative consequences in dairy heifers. Decreasing age at puberty may reduce prepubertal mammary gland development by reducing the length of the allometric phase of mammary gland growth (Meyer et al., 2004a,b). Although estrogen is the dominant gonadal steroid circulating before puberty, the concentrations are relatively low (Rodrigues et al., 2002). At puberty, the relatively high circulating concentrations of estrogen may reduce bone growth, particularly that of the long bones (Chagin et al., 2004). Thus, decreasing the duration of the prepubertal growth phase may slow or limit skeletal growth. The correlation of body size to milk production at first lactation is greater than the correlation of $\mathrm{BW}$ to milk pro- 
duction at first lactation (Heinrichs and Hargrove, 1987). Therefore, limiting skeletal growth of dairy heifers may reduce subsequent milk yields. In addition to limiting mature body size, rapid growth may affect body composition and negatively influence subsequent lactations. Accelerating body growth by feeding diets that are high in energy promotes fat accumulation, which impairs mammary growth in the prepubertal dairy heifer (Capuco et al., 1995, 2003; Sejrsen and Purup, 1997, Sejrsen et al., 2000). Promoting lean growth may overcome the negative influence of accelerating growth through dietary manipulation. Moallem et al. (2004a,b) showed that administration of bST to growing dairy heifers promotes lean growth, and RUP feeding in combination with bST accelerates lean skeletal growth in prepubertal dairy heifers. The effect of additional dietary RUP on skeletal growth rates was greatest from 90 to $150 \mathrm{~d}$ of age and diminished thereafter, suggesting that metabolizable protein was limiting in early life. In contrast, the effect of bST tended to be greater around puberty, but only in the presence of supplemental RUP. Therefore, additional metabolizable protein may improve the response of heifers exposed to LDPP.

We hypothesized that the potential negative effects of accelerating growth and hastening puberty of dairy heifers through exposure to LDPP could be overcome by providing greater supply of metabolizable protein through RUP feeding. The objectives of the slaughter study were to determine the influence of photoperiod on mammary growth and to compare the slaughter (i.e., direct chemical analysis of tissue composition) and deuterium oxide $\left(\mathrm{D}_{2} \mathrm{O}\right)$ dilution methods for assessment of body composition in prepubertal heifers exposed to LDPP or short-day photoperiod (SDPP). A second growth study was conducted to determine whether LDPP in combination with RUP could promote lean growth without limiting body size in the prepubertal heifer.

\section{MATERIALS AND METHODS}

\section{Experimental Design}

For the slaughter study, 20 weaned Holstein heifers ( $84 \pm 15 \mathrm{~d}$ of age), were purchased from a commercial producer, and maintained in natural photoperiod conditions for $7 \mathrm{~d}$ as a pretreatment period to acclimate to a new diet. All animals were in good health and vaccinated according to general management procedures of the University of Illinois Dairy Center. The diet was a TMR formulated as the control diet presented in Table 1. Animals were fed to ad libitum intake at $1000 \mathrm{~h}$ each day. Calves were housed in identical pens within the Photoperiod Research Barn at the University of Illinois Dairy Center. Each pen was lit by metal halide bulbs
Table 1. Chemical analysis and composition of diet fed to heifers exposed to long-day photoperiod or short-day photoperiod from 3 mo of age until the onset of puberty.

\begin{tabular}{lcc}
\hline $\begin{array}{l}\text { Nutrient composition } \\
\text { (DM basis) }\end{array}$ & Control diet & RUP diet \\
\hline $\mathrm{CP}, \%$ & 16.9 & 16.7 \\
$\mathrm{ADF}, \%$ & 23.3 & 23.6 \\
$\mathrm{NDF}, \%$ & 32.4 & 35.4 \\
$\mathrm{NE}_{\mathrm{M}}{ }^{1}{ }^{1} \mathrm{Mcal} / \mathrm{kg}$ & 1.69 & 1.65 \\
$\mathrm{NE}_{\mathrm{G}}, \mathrm{Mcal} / \mathrm{kg}$ & 1.08 & 1.04 \\
Ingredient, $\%$ & & \\
Corn silage & 51.9 & 51.9 \\
Alfalfa silage & 23.3 & 23.3 \\
Corn grain, ground & 14.1 & 11.9 \\
Soybean meal, 48\% CP & 9.5 & 7.9 \\
Fish meal & - & 4.0 \\
Limestone & 0.17 & 0.17 \\
Dicalcium phosphate & 0.17 & 0.17 \\
Salt, white & 0.35 & 0.35 \\
Mineral-vitamin mix ${ }^{2}$ & 0.17 & 0.17 \\
\hline
\end{tabular}

${ }^{1} \mathrm{NE}_{\mathrm{M}}=$ Net energy for maintenance; $\mathrm{NE}_{\mathrm{G}}=$ net energy for gain.

${ }^{2}$ Vitamin A, 2,200,000 IU/kg; vitamin D, 660,000 IU/kg; vitamin E, 22,000 IU/kg; K, 7.5\%; Fe, 2.0\%; Zn, 3.0\%; Mn, 3.0\%; Cu, 5,000 ppm; Co, 40 ppm; I, 250 ppm; Se,150 ppm.

to an average illumination intensity of $450 \mathrm{~lx}$ at a height of $1 \mathrm{~m}$ above the stall floor. Although only 2 pens were used for this initial study, heifer was used as the experimental unit, as each animal received light individually, albeit from the same overall source. It can be argued that pen per se may influence the response, and photoperiod and pen are confounded, yet in previous studies we have not observed an effect of pen on photoperiodic responses in this (Auchtung et al., 2004, 2005) or other facilities (Auchtung et al., 2003; Kendall et al., 2003).

After the acclimation period, all calves were allocated to individual pens and then subjected to a study of body composition using $\mathrm{D}_{2} \mathrm{O}$ dilution methodology (Andrew et al., 1995; Auchtung et al., 2002) to determine total body water. On d 6, 4 animals were slaughtered ( 62.5 $\pm 42 \mathrm{~d}$ old, $\mathrm{BW}=83.1 \pm 33.3 \mathrm{~kg}$ ) and subjected to a chemical analysis to provide a baseline of body composition. The remaining 16 calves $(\mathrm{BW}=94.3 \pm 6.8 \mathrm{~kg}$ ) were randomly allotted to 1 of 2 photoperiod treatment groups [LDPP (16 light:8 dark) or SDPP (8 light:16 dark)] until slaughter on experimental d 70 or 140 . The $\mathrm{D}_{2} \mathrm{O}$ dilution methodology was conducted before each slaughter. Four animals per treatment were slaughtered at approximately 5 and $7 \mathrm{mo}$ of age to determine the effect of LDPP and SDPP on composition and to allow for comparison of the $\mathrm{D}_{2} \mathrm{O}$ and direct chemical estimations of body composition. Mammary glands were also collected for determination of photoperiod treatment on measures of mammary growth and composition.

For the main growth experiment, an additional 32 weaned heifers $(86 \pm 2 \mathrm{~d}$ old; $\mathrm{BW}=106.2 \pm 17.3 \mathrm{~kg})$ 
were assigned to 1 of 4 treatments in a randomized complete block design and $2 \times 2$ factorial arrangement until the onset of puberty, assessed by progesterone concentration in plasma. The treatments were photoperiod (LDPP or SDPP) and diet (control or RUP-supplemented diet). Heifers were housed similarly to those in the slaughter study except that there were 3 pens of each dietary treatment within a photoperiodic treatment, for a total of 12 pens. Each pen contained 2 or 3 animals, all on the same dietary by photoperiodic treatment. As in the slaughter study, animal was considered the experimental unit. Heifers were assigned to treatments in 3 groups on October 18, $2002(\mathrm{n}=8$; group 1), December 5, $2002(\mathrm{n}=12$; group 2), and January 24,2003 ( $\mathrm{n}=12$; group 3$)$.

The RUP-supplemented diet contained fish meal ( $2 \%$ on a DM basis) to increase the RUP level. The protein content of each diet was balanced to $16 \%$ according to NRC (2001) recommendations. Control animals received an identical forage diet with the addition of soybean meal instead of fish meal to fulfill the protein requirement. The diet was adjusted every $14 \mathrm{~d}$ to account for changes in the DM content of the ingredients. Feed was offered ad libitum once daily after refusals were collected. Weekly samples of each TMR were analyzed for chemical composition (Table 1).

In the growth experiment BW, withers height (WH), hip height (HH), and heart girth (HG) were recorded on $\mathrm{d}-1$ of the experiment and every $14 \mathrm{~d}$ thereafter during the experimental period until the onset of puberty, and during posttreatment until heifers reached the breeding target of BW $(375 \mathrm{~kg})$ and $\mathrm{WH}(132 \mathrm{~cm})$. After confirmation of puberty, heifers were removed individually from experimental treatments, commingled among treatments, and housed under natural photoperiod (spring-summer season) in heifer facilities at the University of Illinois Dairy Center. Animals received regular nutritional management for growing heifers according to NRC (2001) recommendations. Collection of skeletal growth data (i.e., $\mathrm{BW}, \mathrm{WH}, \mathrm{HH}$, and HG) continued during the posttreatment period until pregnancy was confirmed, and a final measurement was made at parturition.

\section{$\mathrm{D}_{2} \mathrm{O}$ Dilution}

Seven days before each slaughter, a $\mathrm{D}_{2} \mathrm{O}$ study was conducted to assess the water content of the heifers. Deuterium oxide dilution is a noninvasive technique that provides an economical and repeatable method to describe the body composition of animals throughout their growth period (Shipley and Clark, 1972; Byers, 1979). Because of the association of body water and body composition, a stable isotope such as $\mathrm{D}_{2} \mathrm{O}$ can be used to estimate empty body water (EBW). The positive relationship between EBW, empty body protein (EBP), and empty body mineral (EBM) is used to estimate the protein and mineral content of the empty body weight (EBWT). However, there is an inverse relationship between empty body fat (EBF) and EBW. Blood samples $(10 \mathrm{~mL})$ were collected via jugular venipuncture using a Vacutainer tube and 20-gauge needle (Becton Dickinson Vacutainer Systems, Franklin Lakes, NJ) and immediately chilled in ice. The baseline sample was immediately followed by injection of $300 \mathrm{mg}$ of $\mathrm{D}_{2} \mathrm{O} / \mathrm{kg}$ of $\mathrm{BW}$ in sterile physiological saline $(0.9 \%)$. The syringes containing the $\mathrm{D}_{2} \mathrm{O}$ in physiological saline were weighed before and after administration to record the actual dose of $\mathrm{D}_{2} \mathrm{O}$ injected gravimetrically. The $\mathrm{D}_{2} \mathrm{O}$ was allowed to equilibrate with body water for $1 \mathrm{~h}$. Six blood samples $(10 \mathrm{~mL})$ were taken over $6 \mathrm{~d}(1 / \mathrm{d})$ between 0800 and $1000 \mathrm{~h}$ before feeding to estimate the dilution of the tracer. Blood was centrifuged $(2000 \times g$ for 30 min, $4^{\circ} \mathrm{C}$ ), and plasma was harvested and stored at $-20^{\circ} \mathrm{C}$ until $\mathrm{D}_{2} \mathrm{O}$ analysis. This analysis consisted of detection of $\mathrm{D}_{2} \mathrm{O}$ by infrared spectroscopy (Miran Fixed Infrared Filter; The Foxboro Co., Bridgewater, MA), using the procedures of Byers (1979) modified for automated sample delivery. The disappearance curve of $\mathrm{D}_{2} \mathrm{O}$ provided the statistic for estimation of EBW.

Two models were used to analyze data for the $\mathrm{D}_{2} \mathrm{O}$ dilution, the 1-pool and 2-pool models; however, we were unable to estimate the statistical parameters using the 2-pool model. The 1-pool model was used to estimate EBW content in 3- and 5-mo-old heifers; however, we were unable to estimate the kinetics of EBW in 7-mo-old heifers.

For the 1-pool model:

$$
\mathrm{Q}_{(\mathrm{t})}=\mathrm{Q}_{0} \times \mathrm{e}^{-\mathrm{kt}}
$$

where $\mathrm{Q}_{(\mathrm{t})}$ is the $\mathrm{D}_{2} \mathrm{O}$ concentration, and $\mathrm{Q}_{0}$ is the concentration at time 0 , e is the natural log base, $\mathrm{k}$ is the constant decay rate; and $t$ is time in min.

\section{Blood Sampling and Hormone Assays}

In the growth experiment, blood samples were collected every 2 wk to monitor circulating progesterone concentrations in a sequential manner. The frequency of sampling increased to once a week when each heifer was approximately $60 \mathrm{~d}$ from its expected puberty date (i.e., 7 mo old). Plasma was separated by centrifugation at $2000 \times g$ for $30 \mathrm{~min}$ and was stored at $-20^{\circ} \mathrm{C}$ until assayed. Heifers were considered pubertal at the first of 2 consecutive samples containing progesterone concentrations greater than $1.0 \mathrm{ng} / \mathrm{mL}$. In both experiments, blood samples were also collected to determine 
prolactin (PRL) concentrations and confirm the effect of photoperiod treatment. Plasma samples were analyzed in duplicate using samples from 3 consecutive days at $d 70$ to 72 and $d 140$ to 142 of the experimental period using a previously validated PRL radioimmunoassay (Miller et al., 1999).

\section{Growth, Development, and Composition}

Slaughter periods were selected to allow investigation of the effect of photoperiod treatment between weaning and before the predicted onset of puberty (Moallem et al., 2004a). Protein, fat, and water were determined in carcass and inedible samples in duplicate (Moallem et al., 2004b). Samples (10 g) for carcass DM determinations were placed in crucibles in an oven $\left(105^{\circ} \mathrm{C}\right)$ for $24 \mathrm{~h}$. Crucibles were removed from the oven and placed in a desiccator at room temperature for 30 min, and dry weight was recorded. Dry matter was estimated from the final weight subtracted from the initial weight. Total nitrogen was determined and CP was calculated as $\mathrm{N} \times 6.25$. Ether extract was determined by AOAC (1984) procedures. Ash content was measured by combustion at $600^{\circ} \mathrm{C}$ for $16 \mathrm{~h}$. Empty body composition of water, protein, fat, and ash for each individual animal was estimated using the weight of the carcass and inedible fractions multiplied by the percentage of each fraction. Udder halves obtained at slaughter were sliced into $\sim 34$-mm sections and parenchyma was dissected from mammary fat. Each fraction was weighed and parenchyma was ground for DNA content determination by Hoechst 33258 dye binding (Labarca and Paigen, 1980). Parenchyma lipid percentage was determined gravimetrically by chloroformmethanol extraction (Folch et al., 1957).

\section{Statistical Analyses}

The software of SAS System v. 9.1 (SAS Inst. Inc., Cary, NC) for the ANOVA in the MIXED procedure provided the statistics for the dependent variables. In the preliminary study, because of the variation in BW between baseline and experimental animals, heifers were blocked for BW. The MIXED procedure from SAS was used to analyze estimated values of EBW, EBP, EBM, and EBF. For the growth study, the analysis of body growth included the covariates of $\mathrm{BW}, \mathrm{WH}, \mathrm{HH}$, and $\mathrm{HG}$ at $\mathrm{d}-1$. The model included time in the REPEATED statement, the fixed effects of photoperiod and diet, and the random effects of heifer and all possible interactions. Each heifer was a subject of the repeated measures statement and was nested within treatment. The variance covariance structure used in the model was autoregressive 1 (AR 1) based on best-fit statistic using Akaike's information criterion (AIC), AIC for small samples, and Bayesian information criterion for the body growth analysis. Further, linear regression and correlation coefficients were determined between age at puberty and different body size parameters (BW, $\mathrm{WH}, \mathrm{HH}$, and HG). Puberty as well as plasma PRL concentrations were analyzed using the MIXED procedure of SAS and the model included the fixed effects of photoperiod and diet, and the random effect of heifer. Student's $t$-test was used to evaluate effects of photoperiod on mammary growth parameters.

\section{RESULTS}

\section{Circulating PRL Concentration}

For the slaughter study, LDPP-treated calves tended to have higher mean concentrations of PRL relative to SDPP animals (11 and $5 \mathrm{ng} / \mathrm{mL}$, respectively; $P=0.17$ ) and there was no effect of time. During the growth study, LDPP generally increased mean PRL concentration relative to SDPP (5.2 vs. $3.7 \mathrm{ng} / \mathrm{mL} ; P=0.026$ ). There was no effect of diet on circulating PRL.

\section{Body Composition}

In the slaughter study, comparisons of body composition determined by a technique using carcass slaughter balance chemical analysis and by the $\mathrm{D}_{2} \mathrm{O}$ technique were made for the baseline and 5 mo-old heifers; however, the third evaluation of body composition, at 7 mo of age, was determined only by chemical analysis. Although there were no significant treatment differences observed for EBWT, EBW, or EBP during the experimental period, SDPP heifers at 7 mo of age accrued less body fat $(P=0.01)$ relative to LDPP heifers (Table 2). Across time, although not significant, body water content decreased on average from 65 to $62 \%$, CP content remained similar at approximately $19 \%$, and fat content increased with age from 11 to $16 \%$, and mean ash declined from 3.5 to $2.5 \%$.

\section{Estimated Body Composition by $\mathrm{D}_{2} \mathrm{O}$ Method}

There were no differences between photoperiod treatments at 5 mo of age for $\mathrm{EBW}(P=0.37), \operatorname{EBP}(P=$ $0.37), \operatorname{EBM}(P=0.36)$, or $\operatorname{EBF}(P=0.65)$. In the present study, we were unable to estimate water kinetics in 7mo-old heifers. The correlation between the chemical and $\mathrm{D}_{2} \mathrm{O}$ techniques to determine water, protein, and mineral content in 3- and 5-mo-old heifers was high (Table 3). However, measurements of fat content using the 2 methods were not correlated in 5-mo-old heifers (Table 3). 
Table 2. Percentage of chemical composition and total content of components gained $(\mathrm{kg})$ for empty body weight in 8 Holstein heifers at 5 and 7 mo of age exposed to long-day photoperiod (LDPP) or shortday photoperiod (SDPP).

\begin{tabular}{|c|c|c|c|c|}
\hline \multirow[b]{2}{*}{ Variable } & \multicolumn{2}{|c|}{ Treatment } & \multirow[b]{2}{*}{ SEM } & \multirow[b]{2}{*}{$P$-value } \\
\hline & SDPP & LDPP & & \\
\hline 5-mo-old heifers, $\mathrm{n}$ & 4 & 4 & & \\
\hline Water, \% & 65.3 & 66.0 & 1.07 & 0.66 \\
\hline Ash, \% & 3.6 & 3.2 & 0.42 & 0.55 \\
\hline $\mathrm{CP}, \%$ & 19.7 & 19.9 & 0.18 & 0.48 \\
\hline Fat, \% & 11.3 & 10.7 & 1.25 & 0.78 \\
\hline \multicolumn{5}{|l|}{ Component, kg } \\
\hline Weight & 62.6 & 67.0 & 6.06 & 0.62 \\
\hline Water & 40.7 & 44.2 & 3.95 & 0.55 \\
\hline Ash & 2.2 & 2.1 & 0.20 & 0.74 \\
\hline $\mathrm{CP}$ & 12.3 & 13.3 & 1.19 & 0.58 \\
\hline Fat & 6.9 & 6.7 & 0.66 & 0.83 \\
\hline 7-mo-old heifers, $\mathrm{n}$ & 4 & 4 & & \\
\hline Water, \% & 62.7 & 61.8 & 1.17 & 0.59 \\
\hline Ash, \% & 2.7 & 2.0 & 0.49 & 0.36 \\
\hline $\mathrm{CP}, \%$ & 19.4 & 19.5 & 0.46 & 0.79 \\
\hline Fat, $\%$ & 15.1 & 16.5 & 1.69 & 0.56 \\
\hline \multicolumn{5}{|l|}{ Component, kg } \\
\hline Weight & 144.2 & 150.2 & 3.80 & 0.31 \\
\hline Water & 90.4 & 92.8 & 2.37 & 0.49 \\
\hline Ash & 3.2 & 3.0 & 0.09 & 0.12 \\
\hline $\mathrm{CP}$ & 27.9 & 29.3 & 0.75 & 0.26 \\
\hline Fat & 21.7 & 24.7 & 0.57 & 0.01 \\
\hline
\end{tabular}

\section{Overall Growth Response}

The second group of heifers (group $2 ; \mathrm{n}=12$ ) on the growth study had markedly slower BW gain overall relative to groups 1 and 3 (Figure 1; Tables 4 and 5). This reduced rate of gain was apparent regardless of treatment and may have resulted from cold stress due to low ambient temperature, low stocking density, and sand bedding. These conditions were especially severe during the early stages of the experimental period for group 2 (i.e., December and January) relative to groups 1 and 3 that began treatments under milder ambient temperatures in October and late January. Because of this potential limitation in the design and increase in variability, results of growth variables were analyzed with and without the second block of heifers. Exclusion of group 2 revealed significant treatment effects on growth variables that were masked when all calves were included in the analysis, likely because of the reduced overall variability among animals. Therefore, data from group 2 were removed from the final statistical analyses, leaving 20 heifers as reported below. However, a summary of group 2 data is presented separately in Table 5.

\section{Assessment of Puberty}

In the growth study, relative to SDPP, LDPP hastened the onset of puberty by $24 \mathrm{~d}$ (Table 4 ). There was no effect of diet on age of puberty (Table 4). Further, the correlation coefficients between pubertal age and BW were similar for both LDPP and SDPP heifers ( $\mathrm{r}=$ $0.71)$. However, the correlation between pubertal age and $\mathrm{WH}$ was higher in $\operatorname{SDPP}(\mathrm{r}=0.83)$ relative to $\mathrm{LDPP}$ heifers $(r=0.52)$.

\section{Body Growth and Mammary Development}

Relative to SDPP, LDPP promoted BW gain $(P=0.02$; Figure 2). Exposure to LDPP increased average daily gain compared with SDPP (Table 4). Relative to SDPP, LDPP heifers gained significantly $(P=0.009)$ more height at the withers. Heifers supplemented with RUP tended to be taller $(P=0.06)$ than control animals. There was a significant interaction between photoperiod and diet, in which LDPP and RUP increased $(P=$ $0.001) \mathrm{HH}$ accumulation during the experimental period (Figure 3). Long-day photoperiod $(P=0.03)$ and RUP supplementation $(P=0.005)$ increased HG.

In the slaughter study, photoperiod did not affect the mass of mammary parenchyma $(P=0.45)$ or mammary

Table 3. Mean estimates $(\mathrm{kg})$ of body components derived from carcass chemical analysis and $\mathrm{D}_{2} \mathrm{O}$ dilution for water, protein, mineral, and fat content in 3-mo-old $(n=4)$ and 5-mo-old heifers $(n=8)$. Correlations between the 2 methods at both ages were evaluated relative to total empty body weight.

\begin{tabular}{lllll}
\hline & \multicolumn{3}{c}{ Component } \\
\cline { 2 - 5 } & Water & Protein & Mineral & Fat \\
\hline 3-mo-old heifers & & & & \\
Chemical & $49.7 \pm 24.1$ & $13.4 \pm 7.3$ & $2.4 \pm 1.5$ & $4.1 \pm 3.9$ \\
$\mathrm{D}_{2} \mathrm{O}$ & $61.9 \pm 43.2$ & $18.6 \pm 13.1$ & $4.2 \pm 2.9$ & $1.7 \pm 10.8$ \\
$\mathrm{r}$ & 0.99 & 0.99 & 0.87 & 0.96 \\
$P$ & 0.003 & 0.002 & 0.12 & 0.03 \\
5 -mo-old heifers & & & & \\
Chemical & $82.0 \pm 19.6$ & $23.4 \pm 6.3$ & $3.9 \pm 0.9$ & $6.4 \pm 6.1$ \\
$\mathrm{D}_{2} \mathrm{O}$ & $121.2 \pm 26.6$ & $32.5 \pm 8.3$ & $7.4 \pm 1.8$ & $11.0 \pm 21.0$ \\
$\mathrm{r}$ & 0.85 & 0.86 & 0.76 & -0.068 \\
$P$ & 0.006 & 0.006 & 0.026 & 0.87 \\
\hline
\end{tabular}




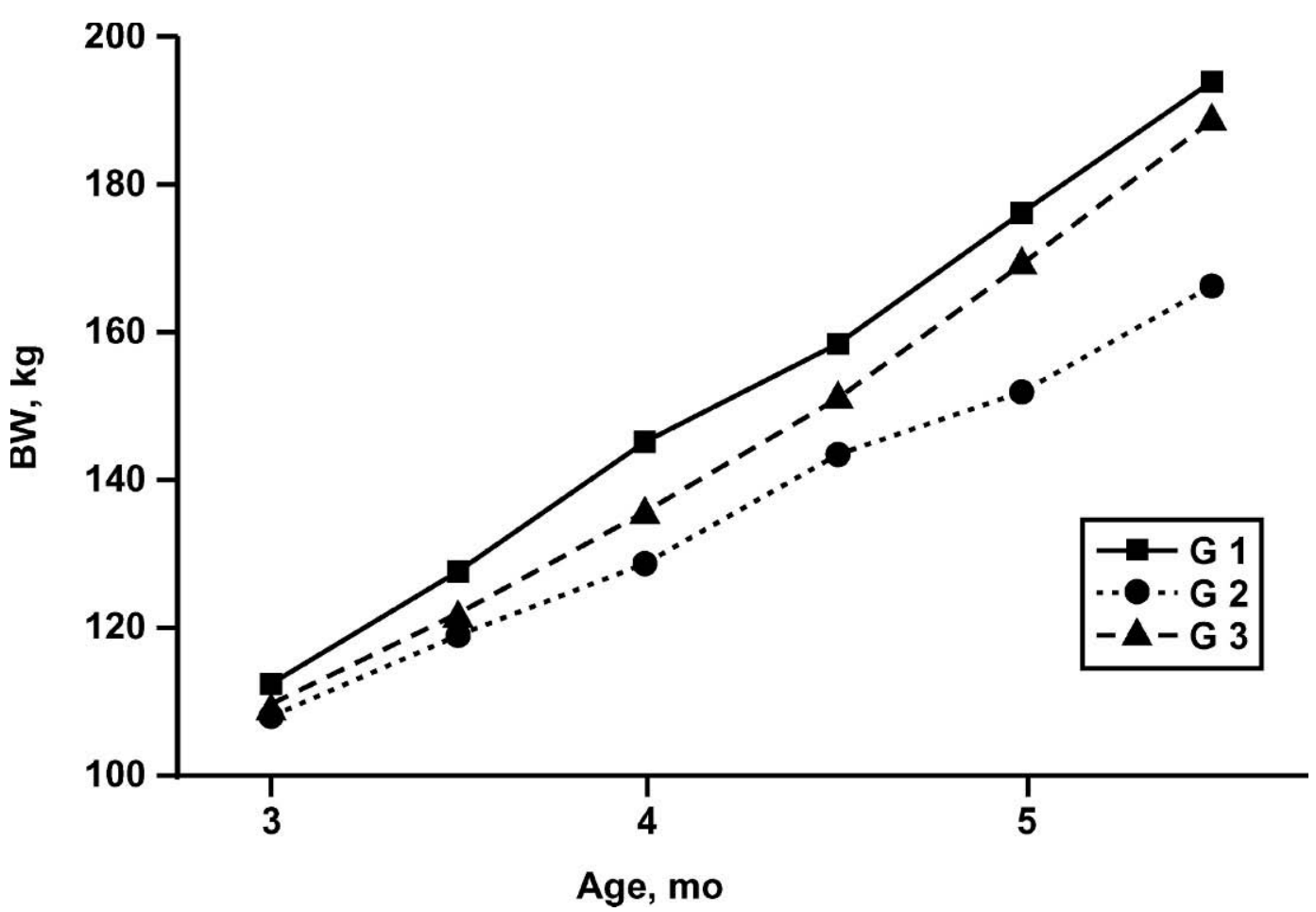

Figure 1. Body weight (BW) of prepubertal heifers from 3 to 5.5 mo of age $(\mathrm{n}=32)$ assigned to treatment in 3 groups: G1 ( $\mathbf{\square}), \mathrm{n}=8$, $\mathrm{SEM}=7.8 ; \mathrm{G} 2(\bullet), \mathrm{n}=12, \mathrm{SEM}=6.3 ;$ and $\mathrm{G} 3(\mathbf{\Delta}), \mathrm{n}=12, \mathrm{SEM}=6.3$. Groups 1 and 3 have similar slopes compared with G2, where function for G1 $=16.2 \times \mathrm{X}+95.4, \mathrm{G} 2=11.5 \times \mathrm{X}+95.8$ and G3 $=16.0 \times \mathrm{X}+90.5$. There was significant interaction between group and time $(P=0.001)$.

fat pad $(P=0.91)$, although both increased with age. Similarly, total parenchymal DNA $(P=0.32)$ and parenchymal lipid content $(P=0.62)$ were unaffected by photoperiod.

\section{DISCUSSION}

Concentration of PRL in blood of cattle varies with season (Koprowski and Tucker, 1973) and ambient stress conditions (Ronchi et al., 2001). Overall, PRL concentrations allow us to confirm the photoperiodic effect. In the present studies, PRL remained at low levels, although LDPP increased circulating concentrations of PRL, particularly in the growth study. Other authors (Peters and Tucker 1978; Peters et al., 1980; Zinn et al., 1986) reported that severe cold stress depresses PRL secretion in growing heifers. In the present growth study, we found similar results in that cold ambient temperature depressed PRL secretion in LDPP animals. As previously reported by Peters et al. (1980), the prepubertal heifer is affected by low ambient temperature, and temperatures below $0{ }^{\circ} \mathrm{C}$ may block the photoperiodic effect, thus depressing circulating PRL. In contrast, high ambient temperatures are associated

Table 4. Estimates of prolactin (PRL), average daily gain (ADG), and age of puberty in heifers of group 1 and $3(n=20)$ treated with long day (LDPP) or short day photoperiod (SDPP) and rumen undegradable protein (RUP) or control diet (control) from 3 mo of age to puberty. Prolactin analysis was conducted at baseline (1 PRL), $70 \mathrm{~d}$ (2 PRL), and $140 \mathrm{~d}$ on treatment (3 PRL).

\begin{tabular}{|c|c|c|c|c|c|c|c|}
\hline \multirow[b]{2}{*}{ Trait } & \multirow[b]{2}{*}{ SDPP } & \multirow[b]{2}{*}{ LDPP } & \multirow[b]{2}{*}{ Control } & \multirow[b]{2}{*}{ RUP } & \multicolumn{3}{|c|}{$P$-value } \\
\hline & & & & & Photoperiod & Diet & $\begin{array}{l}\text { Photoperiod } \\
\times \text { Diet }\end{array}$ \\
\hline $1 \mathrm{PRL}, \mathrm{ng} / \mathrm{mL}$ & $0.6 \pm 0.1$ & $0.7 \pm 0.1$ & $0.7 \pm 0.1$ & $0.6 \pm 0.1$ & 0.79 & 0.74 & 0.33 \\
\hline $2 \mathrm{PRL}, \mathrm{ng} / \mathrm{mL}$ & $2.7 \pm 0.5$ & $3.8 \pm 0.5$ & $3.0 \pm 0.5$ & $3.4 \pm 0.5$ & 0.15 & 0.61 & 0.85 \\
\hline $3 \mathrm{PRL}, \mathrm{ng} / \mathrm{mL}$ & $5.0 \pm 0.6$ & $6.5 \pm 0.6$ & $5.6 \pm 0.6$ & $5.8 \pm 0.6$ & 0.09 & 0.77 & 0.31 \\
\hline Puberty, d & $285 \pm 7$ & $261 \pm 7$ & $268 \pm 7$ & $274 \pm 7$ & 0.05 & 0.57 & 0.89 \\
\hline $\mathrm{ADG}, \mathrm{g} / \mathrm{d}$ & $1131 \pm 32$ & $1227 \pm 32$ & $1172 \pm 32$ & $1185 \pm 32$ & 0.01 & 0.74 & 0.96 \\
\hline
\end{tabular}


Table 5. Estimates of prolactin (PRL), average daily gain (ADG), and age of puberty in heifers of group 2 $(\mathrm{n}=12)$ treated with long-day (LDPP) or short-day photoperiod (SDPP) and RUP or control diet from 3 mo of age to puberty. Prolactin analysis was conducted at baseline (1 PRL), $70 \mathrm{~d}$ ( 2 PRL), and $140 \mathrm{~d}$ on treatment (3 PRL).

\begin{tabular}{|c|c|c|c|c|c|c|c|}
\hline \multirow[b]{2}{*}{ Trait } & \multirow[b]{2}{*}{ SDPP } & \multirow[b]{2}{*}{ LDPP } & \multirow[b]{2}{*}{ Control } & \multirow[b]{2}{*}{ RUP } & \multicolumn{3}{|c|}{$P$-value } \\
\hline & & & & & Photoperiod & Diet & $\begin{array}{l}\text { Photoperiod } \\
\times \text { Diet }\end{array}$ \\
\hline $1 \mathrm{PRL}, \mathrm{ng} / \mathrm{mL}$ & $0.5 \pm 0.1$ & $0.3 \pm 0.1$ & $0.4 \pm 0.1$ & $0.4 \pm 0.1$ & 0.20 & 0.99 & 0.20 \\
\hline 2 PRL, ng/mL & $1.2 \pm 0.3$ & $2.1 \pm 0.3$ & $1.3 \pm 0.3$ & $2.0 \pm 0.3$ & 0.08 & 0.19 & 0.87 \\
\hline $3 \mathrm{PRL}, \mathrm{ng} / \mathrm{mL}$ & $8.8 \pm 1.8$ & $10.8 \pm 1.8$ & $11.0 \pm 1.8$ & $8.6 \pm 1.8$ & 0.45 & 0.35 & 0.50 \\
\hline Puberty, d & $278 \pm 9.5$ & $262 \pm 9.5$ & $278 \pm 9.5$ & $262 \pm 9.5$ & 0.27 & 0.28 & 0.88 \\
\hline $\mathrm{ADG}, \mathrm{g} / \mathrm{d}$ & $1121 \pm 42$ & $1090 \pm 42$ & $1045 \pm 42$ & $1165 \pm 42$ & 0.51 & 0.01 & 0.33 \\
\hline
\end{tabular}

with increases in PRL (Tucker et al., 1991). Thus, the relatively higher concentrations observed in the slaughter study vs. the growth study result from differences in ambient temperature. That is, calves in the slaughter study were exposed to high temperatures of the summer, whereas heifers in the growth study were treated during fall and winter.

Body composition, assessed by direct chemical balance analysis, followed a similar pattern as expected from previous studies (Petitclerc et al., 1983; Zinn et al., 1986). In general, the protein content of the carcass remained relatively constant during development, whereas the fat content increased with age in growing animals. However, at 7 mo of age, there was no significant effect of photoperiod in body composition. Estimation of EBW dynamics by the $\mathrm{D}_{2} \mathrm{O}$ methodology allowed for estimation of body composition across time in 3 - and 5 -mo-old heifers and the results were consistent with direct chemical analyses. The 2-pool model described by Shipley and Clark (1972) was not used due to failure to estimate the second pool. In mature animals, it is crucial to harvest an appropriate number of samples (Woodford et al., 1984; Andrew et al., 1995) for accurate estimation of pool sizes, and ultimately body composition. In an earlier study using dairy cows, Woodford et al. (1984) harvested blood every 10 min for the first $4 \mathrm{~h}$

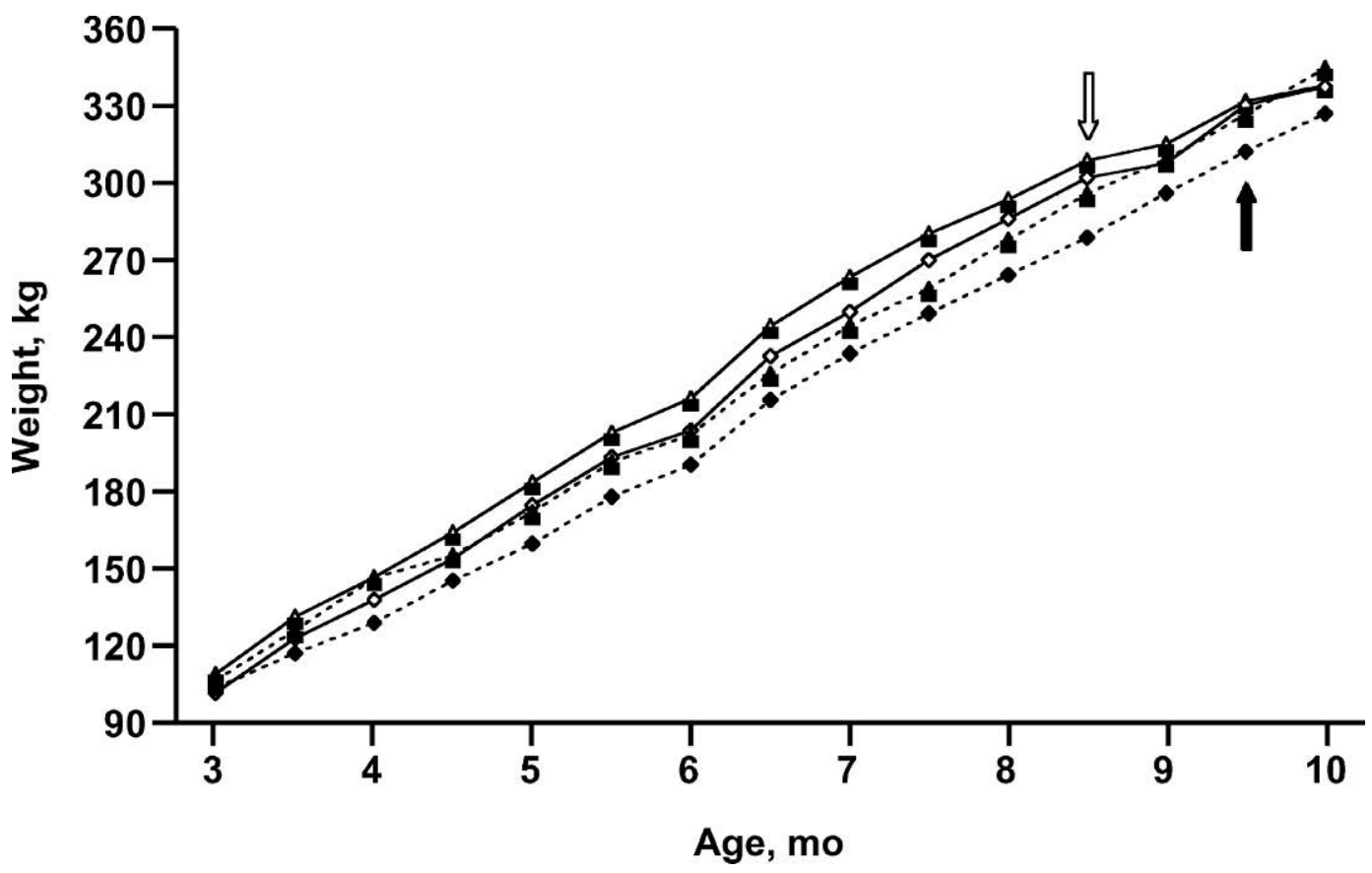

Figure 2. Body weight of prepubertal heifers aged 3 to $10 \mathrm{mo}(\mathrm{n}=20)$ treated with long-day (LDPP) or short-day photoperiod (SDPP) and RUP or control (non-RUP supplemented) diets. The open and closed arrows represent the age of puberty in LDPP and SDPP groups, respectively. The open triangles represent LDPP + diet supplemented with a source of RUP and the open diamonds represent LDPP + control diet. The solid triangles represent SDPP + RUP. The solid diamonds represent SDPP + control diet. Pooled SEM was $4.7 \mathrm{~kg}$ among treatments. Relative to SDPP, LDPP increased gains in BW $(P=0.02)$. 


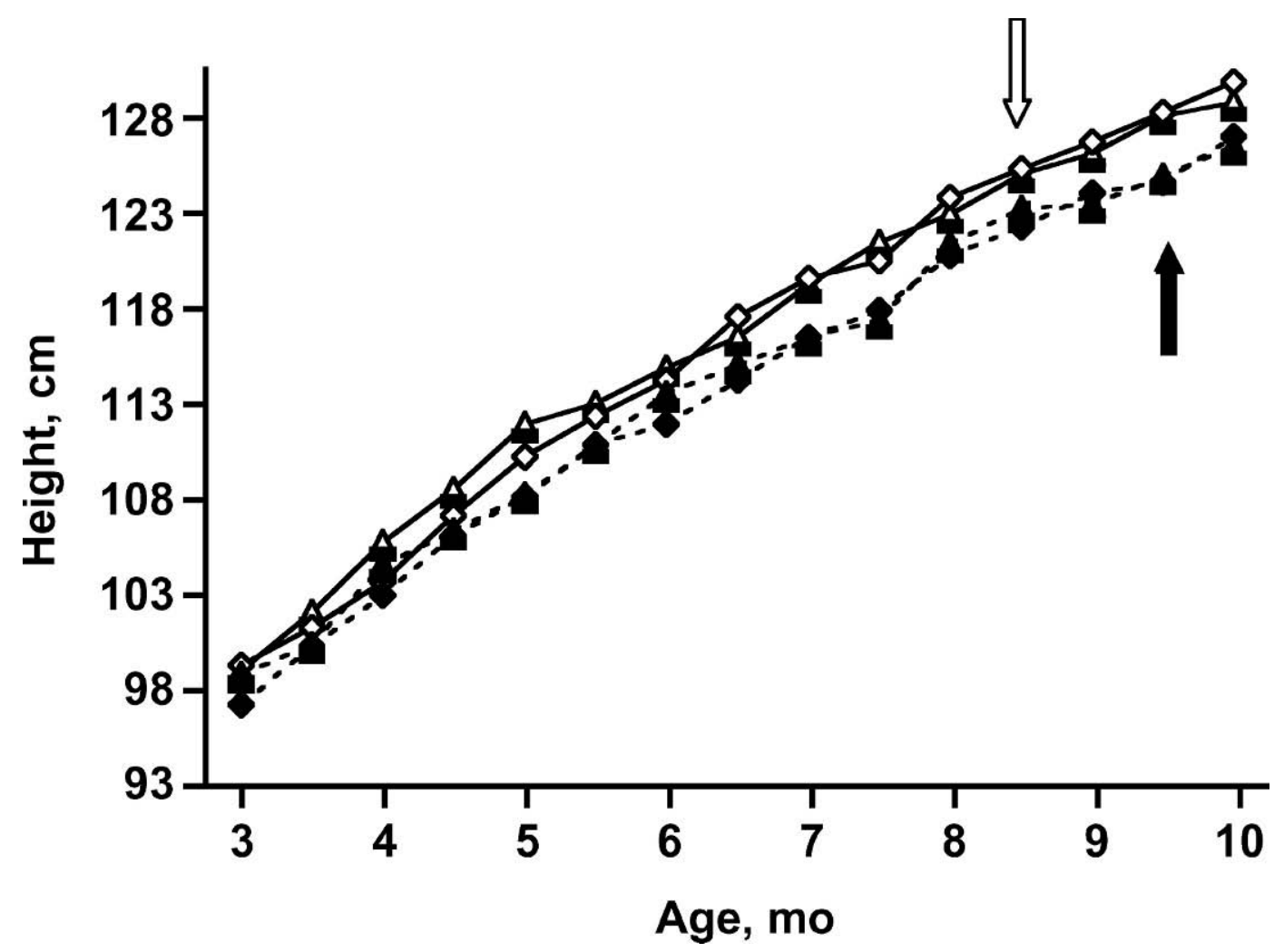

Figure 3. Hip height $(\mathrm{HH})$ of prepubertal Holstein heifers aged 3 to $10 \mathrm{mo}(\mathrm{n}=20)$ treated with long-day (LDPP) or short-day photoperiod (SDPP) and RUP or control diet (non RUP-supplemented). The open and closed arrows represent the age of puberty in LDPP and SDPP groups, respectively. The open triangles represent LDPP + RUP and the open diamonds represent LDPP + control diet. The solid triangles represent SDPP + RUP diet. The solid diamonds represent SDPP + control diets. Pooled SEM was $0.4 \mathrm{~cm}$ among treatments.

after injection of the tracer and during the equilibration phase of the tracer with water in the body. However, in a study conducted in our laboratory using preweaned calves (Auchtung et al., 2002), a smaller number of samples were sufficient to obtain an accurate $\mathrm{D}_{2} \mathrm{O}$ dilution curve. Consistent with that study, 3-mo-old heifers in the present study showed a small error term of total body water during the first $\mathrm{D}_{2} \mathrm{O}$ collection period, probably because the gastrointestinal tract in young animals is not yet fully developed. The $\mathrm{D}_{2} \mathrm{O}$ method had greater variance in estimation of total body water in heifers at 5 and $7 \mathrm{mo}$ of age, again suggesting that greater sampling frequency is required to accurately predict EBW as animals mature and the gastrointestinal tract develops more fully. Overall, the estimation of carcass composition by the $\mathrm{D}_{2} \mathrm{O}$ method was similar to the chemical analyses for water, protein, and minerals, but not fat content. These results provide evidence that the $\mathrm{D}_{2} \mathrm{O}$ dilution technique is appropriate to estimate water, protein, and ash (i.e., lean body components) in young heifers.

Reported effects of photoperiod treatment on prepubertal mammary growth are inconsistent. Studies have shown that long days either have no effect on mammary parenchymal growth (Petitclerc et al., 1984; Ringuet et al., 1989) or increase parenchymal growth (Petitclerc et al., 1985). These discrepancies may be the result of separate influences of photoperiod on rate of mammary growth and duration of allometric mammary growth (which terminates peripubertally). In the present study, there were no differences in mass of mammary parenchyma or extraparenchymal fat between LDPPand SDPP-treated heifers. Furthermore, photoperiod treatment did not affect parenchymal DNA or lipid content. Our results suggest that mammary growth is not influenced by manipulation of day length during the prepubertal period.

Consistent with several other studies (Peters et al., 1980; Hansen et al., 1983; Schillo et al., 1983), LDPP accelerated the onset of puberty relative to that of SDPP heifers. Further, the onset of puberty may be associated with lean tissue accumulation. Therefore, heifers exposed to LDPP may have accumulated total lean tissue at puberty sooner than heifers exposed to SDPP. Heifers exposed to LDPP tended to be smaller in weight and height at pubertal age because they achieved pu- 
berty $21 \mathrm{~d}$ sooner than those exposed to SDPP. Importantly, earlier puberty did not impair ultimate skeletal growth as measured by BW, WH, HH, and HG, or mammary development. Because ultimate stature was not depressed in LDPP animals despite their earlier puberty, it appears that accelerating sexual maturity does not diminish ultimate growth under these conditions. Therefore, in the present study, we confirmed that LDPP promoted body growth in prepubertal heifers. In addition, a greater supply of RUP appeared to have a beneficial effect on $\mathrm{BW}, \mathrm{WH}$, and $\mathrm{HH}$ growth prepubertally. However, after the attainment of puberty, animals previously under SDPP during the treatment period grew faster than animals initially exposed to LDPP. Of interest, LDPP and SDPP heifers were moved into a natural photoperiod condition upon the onset of puberty at a time of year that coincided with a spring-summer photoperiod pattern. The transfer of heifers exposed to SDPP during the experiment into extended lighting conditions after puberty may have activated a compensatory mechanism that promoted growth in these animals relative to heifers exposed to LDPP, which, in contrast, actually saw a relative decrease in daylength.

Although the present study generally supports the concept that extended lighting is beneficial to heifer growth, the observation that LDPP may have limited effect under cold ambient temperatures cannot be discounted. The housing conditions of these heifers, however, were somewhat atypical for the industry, particularly with regard to stocking density and bedding. The sand stalls and concrete floors may have adversely affected the heifers that began treatment in December more so than those that began treatment under less extreme temperatures in October and late January, and the observation of growth rate depression supports that explanation. Under industry standard stocking density and bedding approaches that would limit heat loss, particularly in colder climates, the growth depression overall would be less. It is also important to note that LDPP did not negatively influence growth relative to SDPP, but rather, the expected improvement was not observed.

\section{CONCLUSIONS}

The $\mathrm{D}_{2} \mathrm{O}$ method provides similar results to chemical analysis of composition of lean components; however, it appears to be unsuitable for estimating fat content.

Heifers exposed to LDPP have greater growth and an earlier onset of puberty compared with heifers exposed to SDPP. Moreover, relative to SDPP, LDPP combined with a diet supplemented with RUP promotes growth at a higher rate, as measured by $\mathrm{WH}$ and $\mathrm{HH}$ gain. Photoperiod in combination with elevated dietary RUP provides a feasible management tool to the modern dairy industry to accelerate growth and puberty without limiting body size at breeding.

\section{ACKNOWLEDGMENTS}

The authors thank Jennifer Dauderman, Heather Crawford, Doug Hilgendorf, Gerhard Roth and the dairy farm crew for their assistance in conducting this research.

\section{REFERENCES}

Andrew, S. M., R. A. Erdman, and D. R. Waldo. 1995. Prediction of body composition of dairy cows at three physiological stages from deuterium oxide and urea dilution. J. Anim. Sci. 78:1083-1095.

AOAC. 1984. Official Methods of Analysis. 12th ed. Association of Official Analytical Chemists, Washington, DC.

Auchtung, T. L., D. J. Baer, R. A. Erdman, S. M. Barao, and G. E. Dahl. 2002. Relation of growth hormone response to growth hormone-releasing hormone to estimation of milk production via deuterium oxide dilution in beef cattle. J. Anim. Sci. 80:12701274.

Auchtung, T. L., P. E. Kendall, J. Salak-Johnson, T. B. McFadden, and G. E. Dahl. 2003. Photoperiod and bromocriptine treatment effects on expression of prolactin receptor mRNA in bovine liver, mammary gland and peripheral blood lymphocytes. J. Endocrinol. 179:347-356.

Auchtung, T. L., A. G. Rius, P. E. Kendall, T. B. McFadden, and G. E. Dahl. 2005. Effects of photoperiod during the dry period on prolactin, prolactin receptor and milk production of dairy cows. J. Dairy Sci. 88:121-127.

Auchtung, T. L., J. L. Salak-Johnson, D. E. Morin, C. C. Mallard, and G. E. Dahl. 2004. Effects of photoperiod during the dry period on cellular immune function of dairy cows. J. Dairy Sci. 87:3683-3689.

Byers, F. M. 1979. Measurement of protein and fat accretion in growing beef cattle through isotope dilution procedures. Ohio Beef Cattle Res. Progress Rep. Anim. Sci. Ser. 79. Ohio Agric. Res. Dev. Cen., Wooster.

Capuco, A. V., R. Erdman, G. Dahl, M. Meyer, and M. Van Amburgh. 2003. Heifer Nutrition Prepubertal Growth and Development. Proc. 50th Maryland Nutr. Conf. Feed Manufacturers and 1st Mid-Atlantic Nutr. Conf., Timonium, MD. University of Maryland, College Park.

Capuco, A. V., J. J. Smith, D. R. Waldo, and C. E. Rexroad, Jr. 1995. Influence of prepubertal dietary regimen on mammary growth of Holstein heifers. J. Dairy Sci. 78:2709-2725.

Chagin, A. S., M. K. Lindberg, N. Andersson, S. Moverare, J. A. Gustafsson, L. Savendahl, and C. Ohlsson. 2004. Estrogen receptor-beta inhibits skeletal growth and has the capacity to mediate growth plate fusion in female mice. J. Bone Miner. Res. 19:72-77.

Folch, J., M. Lees, and G. H. Sloane Stanley. 1957. A simple method for the isolation and purification of total lipides from animal tissues. J. Biol. Chem. 226:497-509.

Hansen, P. J., L. A. Kamwanja, and E. R. Hauser. 1983. Photoperiod influences age at puberty of heifers. J. Anim. Sci. 57:985-992.

Heinrichs, A. J., and G. L. Hargrove. 1987. Standards of weight and height for Holstein heifers. J. Dairy Sci. 70:653-660.

Kendall, P. E., T. L. Auchtung, K. S. Swanson, R. P. Radcliff, M. C. Lucy, J. K. Drackley, and G. E. Dahl. 2003. Effect of photoperiod on hepatic growth hormone receptor 1A expression in steer calves. J. Anim. Sci. 81:1440-1446.

Koprowski, J. A., and H. A. Tucker. 1973. Serum prolactin during various physiological states and its relationship to milk production in the bovine. Endocrinology 92:1480-1487. 
Labarca, C., and K. Paigen. 1980. A simple, rapid, and sensitive DNA assay procedure. Anal. Biochem. 102:344-352.

Meyer, M. J., A. V. Capuco, D. A. Ross, and M. E. Van Amburgh. 2004b. Prepubertal mammary development in the bovine: Influence of nutrition and age at puberty. 66th Cornell Nutrition Conference, East Syracuse, NY. Cornell Univ., Ithaca, NY.

Meyer, M. J., A. V. Capuco, and M. E. Van Amburgh. 2004a. Effects of energy intake and time to puberty on mammary growth of prepubertal Holstein heifers. J. Dairy Sci. 87(Suppl 1):275.

Miller, A. E., E. P. Stanisiewski, R. A. Erdman, L. W. Douglass, and G. E. Dahl. 1999. Effects of long daily photoperiod and bovine somatotropin (Trobest) on milk yield in cows. J. Dairy Sci. 82:1716-1722.

Moallem, U., G. E. Dahl, E. K. Duffey, A. V. Capuco, and R. A. Erdman. 2004a. Bovine somatotropin and rumen undegradable protein effects on skeletal growth in prepubertal dairy heifers. J. Dairy Sci. 87:3881-3888.

Moallem, U., G. E. Dahl, E. K. Duffey, A. V. Capuco, D. L. Wood, K. R. McLeod, R. L. Baldwin, and R. A. Erdman. 2004b. Bovine somatotropin and rumen-undegradable protein effects in prepubertal dairy heifers: Effects on body composition and organ and tissue weights. J. Dairy Sci. 87:3869-3880.

National Research Council. 2001. Nutrient Requirements of Dairy Cattle. 7th rev. ed. Natl. Acad. Sci., Washington, DC.

Peters, R. R., L. T. Chapin, R. S. Emery, and H. A. Tucker. 1980. Growth and hormonal response of heifers to various photoperiods. J. Anim. Sci. 51:1148-1153.

Peters, R. R., and H. A. Tucker. 1978. Prolactin and growth hormone responses to photoperiod in heifers. Endocrinology 103:229-234.

Petitclerc, D., L. T. Chapin, R. S. Emery, and H. A. Tucker. 1983. Body growth, growth hormone, prolactin and puberty response to photoperiod and plane of nutrition in Holstein heifers. J. Anim. Sci. 57:892-898.

Petitclerc, D., L. T. Chapin, and H. A. Tucker. 1984. Carcass composition and mammary development responses to photoperiod and plane of nutrition in Holstein heifers. J. Anim. Sci. 58:913-919.

Petitclerc, D., R. D. Kineman, S. A. Zinn, and H. A. Tucker. 1985. Mammary growth response of Holstein heifers to photoperiod. J. Dairy Sci. 68:86-90.

Ringuet, H., D. Petitclerc, M. T. Sorensen, P. Gaudreau, G. Pelletier, J. Morisset, Y. Couture, and P. Brazeau. 1989. Effect of human somatotropin-releasing factor and photoperiods on carcass parameters and mammary gland development of dairy heifers. J. Dairy Sci. 72:2928-2935.

Rodrigues, H. D., J. E. Kinder, and L. A. Fitzpatrick. 2002. Estradiol regulation of luteinizing hormone secretion in heifers of two breed types that reach puberty at different ages. Biol. Reprod. 66:603-609.

Ronchi, B., G. Stradaioli, A. Verini Supplizi, U. Bernabucci, N. Lacetera, P. A. Accorsi, A. Nardone, and E. Seren. 2001. Influence of heat stress or feed restriction on plasma progesterone, oestradiol17 Beta, LH, FSH, prolactin and cortisol in Holstein heifers. Livest. Prod. Sci. 68:231-241.

SAS Institute. 2000. SAS User's Guide. Statistics, version 9.1 ed. SAS Inst., Inc., Cary, NC

Schillo, K. K., P. J. Hansen, L. A. Kamwanja, D. J. Dierschke, and E. R. Hauser. 1983. Influence of season on sexual development in heifers: Age at puberty as related to growth and serum concentrations of gonadotropins, prolactin, thyroxine and progesterone. Biol. Reprod. 28:329-341.

Sejrsen, K., and S. Purup. 1997. Influence of prepubertal feeding level on milk yield potential of dairy heifers: A review. J. Anim. Sci. 75:828-835.

Sejrsen, K., S. Purup, M. Vestergaard, and J. Foldager. 2000. High body weight gain and reduced bovine mammary growth: Physiological basis and implications for milk yield potential. Domest. Anim. Endocrinol. 19:93-104.

Shipley, R. A., and R. E. Clark. 1972. Compartment analysis: Two pool open systems. Pages 21-44 in Tracer methods for in vivo kinetics. Academic Press Inc., New York, NY.

Tucker, H. A., L. T. Chapin, K. J. Lookingland, K. E. Moore, G. E. Dahl, and J. M. Evers. 1991. Temperature effects on serum prolactin concentrations and activity of dopaminergic neurons in the infundibulum/pituitary stalk of calves. Proc. Soc. Exp. Biol. Med. 197:74-76.

Woodford, S. T., M. R. Murphy, and C. L. Davis. 1984. Water dynamics of dairy cattle as affected by initiation of lactation and feed intake. J. Dairy Sci. 67:2336-2343.

Zinn, S. A., R. W. Purchas, L. T. Chapin, D. Petitclerc, R. A. Merkel W. G. Bergen, and H. A. Tucker. 1986. Effect of photoperiod on growth, carcass composition, prolactin, growth hormone and cortisol in prepubertal and postpubertal Holstein heifers. J. Anim. Sci. 63:1804-1815. 